DOI: 10.46340/eujem.2021.7.3.5

Olena Kudyrko, PhD in Economics

ORCID ID: https://orcid.org/0000-0002-5090-1208

Vinnytsia Institute of Trade and Economics KNUTE, Ukraine

Iryna Krupelnytska, PhD in Economics

ORCID ID: https://orcid.org/0000-0002-2487-3362

Vinnytsia Institute of Trade and Economics KNUTE, Ukraine

Inna Kopchykova, PhD in Economics

ORCID ID: https://orcid.org/0000-0001-7752-1603

Vinnytsia Institute of Trade and Economics KNUTE, Ukraine

\title{
ORGANIZATION OF ACCOUNTING \\ AND BASIC METHODS OF ANALYSIS \\ OF COMMODITY OPERATIONS \\ OF A PHARMACEUTICAL ENTERPRISE
}

\author{
Олена Кудирко, к. е. н. \\ Ірина Крупельницька, к. е. н. \\ Інна Копчикова, к. е. н. \\ Вінницький торговельно-економічний інститут КНТЕУ, Україна

\section{ОРГАНІЗАЦІЯ ОБЛІКУ ТА ОСНОВНІ МЕТОДИ АНАЛІЗУ ТОВАРНИХ ОПЕРАЦІЙ ФАРМАЦЕВТИЧНОГО ПІДПРИЕМСТВА}

\begin{abstract}
Commodity transactions are an important economic element that ensures the implementation of trade activities and are implemented by trade enterprises in accordance with a certain algorithm of actions that corresponds to the strategy of commodity resources management. The effectiveness of any trade enterprises depends significantly on the correctness of accounting for trade transactions, namely inventories and their management. After all, the level of liquidity and competitiveness of the enterprise depends on the success of this process. The article considers the peculiarities of the organization of accounting of commodity transactions and determines their place in the economic activity of trade enterprises. The theoretical provisions of development and implementation of commodity operations management policy are studied. The system and basic methods of analysis of commodity transactions are studied in order to establish the efficiency and validity of the inventory management system. The application of methods of analysis of activity on the example of a pharmaceutical enterprise is carried out. The purpose of the article is to study and clearly identify the features of accounting for commodity transactions, as well as to study the basic methods of analysis of commodity transactions carried out in trade enterprises with the help of analytical indicators. The methodological basis of scientific research is statistical and graphical methods, as well as methods of synthesis, analysis and systematization. The information base of scientific research was the works of domestic and foreign scientists, research of world companies, relevant Internet sources. The proposed basic methods of analysis of commodity transactions will help not only pharmaceutical, but also all commercial enterprises to analyze and regulate their activities, increase profitability and turnover of invested capital. Keywords: accounting, analysis, commodity operations, inventories, pharmaceutical industry.
\end{abstract}

Постановка проблеми. Товарні операції $є$ важливою частиною економічної діяльності торговельних підприємств. Їх реалізація дозволяє забезпечувати ефективне розподілення благ та товарів серед споживачів. Актуальність досліджування підвищується у складних економічних 
умовах. Основні проблеми проявляються саме у сфері управління товарами та їх запасами - різке зниження ліквідності та доступності до оборотних грошових коштів призвело до неможливості проводити ефективні товарні операції. Тому важливо більш якісно проводити облік та аналіз товарних операцій, що дозволить у майбутньому приймати обгрунтовані рішення для здійснення ефективної діяльності підприємств.

Розвиток фармацевтичної галузі як системи неможливий без такої її складової частини, як торгівля, яка $є$ активним учасником фармацевтичного ринку та сполучною ланкою між виробниками i споживачами лікарських засобів. У сучасних умовах господарювання фармацевтична галузь характеризується все більшим ускладненням структури, зумовленим розширенням масштабів діяльності, ростом обсягу циркулюючої по іiї каналах фармацевтичної продукції, збільшенням числа структурних елементів і розмаїттям їх зв'язків. У складних умовах функціонування фармації одним із найважливіших напрямів підвищення ефективності їі діяльності стає вдосконалення управління товарними операціями.

Мета статті. Дослідження та чітке виявлення особливостей здійснення обліку товарних операцій, а також вивчення основних методів аналізу товарних операцій, що здійснюються на підприємствах торгівлі за допомогою аналітичних показників.

Аналіз останніх досліджень і публікацій. Вивченням проблемних питань, пов'язаних із здійсненням обліку товарних операцій підприємств та їх аналіз займалось багато вітчизняних науковців, зокрема М.Т. Білуха, Ю. В. Бакун, Ф.Ф. Бутинець, Б.І. Валуєв, А.М. Герасимович, 3.В. Гуцайлюк, В.І. Єфіменко, В.П. Завгородній, М.В. Кужельний, А.М. Кузьмінський, В. І. Лишенко, Є. В. Мних, Л.В. Нападовська, І.І. Пилипенко, М.С. Пушкар, I.I. Сахарцева, В.В. Сопко, Л.К. Сук, Н. М. Ткаченко, Н.В. Чебанова та інші.

Питання обліку та аналізу виробничих запасів фармацевтичних підприємств вивчали такі вчені, як: Л. В. Титенко, Б.П. Громовик, О.В. Посилкіна, М.І. Небава тощо. Визначаючи фундаментальний внесок названих науковців у розвиток даної проблеми, ми вирішили продовжити досліджувати здійснення обліку товарних операцій та здійснити їх аналіз і приділили увагу саме фармацевтичній галузі на прикладі реально існуючого підприємства ТОВ «ТІІМ».

Виклад основного матеріалу. Товарні запаси $є$ одним 3 основних елементів оборотного капіталу торговельних підприємств. Забезпеченість підприємства даним видом ресурсів сприяє безперебійному обслуговуванню споживачів. Важливого значення при цьому набуває контроль за зберіганням товарів на всіх етапах товароруху. Управління запасами повинно бути направлене на підвищення рентабельності та швидкості обігу вкладеного капіталу ${ }^{1}$. Для цього у процесі управління товарними запасами завжди вирішуються наступні завдання:

- визначення цілей управління, аналіз стану товарних запасів;

- оперативний облік і контроль стану товарних запасів;

- здійснення економічних та організаційно-технічних заходів з формування та регулювання товарних запасів і підтримання їх на оптимальному рівні.

Торговельна діяльність фармацевтичної галузі в Україні регламентується великою кількістю нормативно-правових актів. Широкий спектр нормативно-законодавчої бази з організації обліку товарів на підприємствах торгівлі фармацевтичними товарами вимагає іiї систематизації та локалізації за групами. У зв'язку з цим, бухгалтерський облік як джерело забезпечення управління економічною інформацією потребує якісного оновлення організації бухгалтерського обліку.

Товарні запаси у фармацевтичній галузі - це маса лікарських засобів та інших товарів аптечного асортименту, які належать аптечному закладу, знаходяться на його балансі, перебувають у сфері обігу та підлягають реалізації, а також перебувають у процесі руху зі сфери виробництва усферу споживання ${ }^{2}$.

Загалом процес діяльності може мати операційний або неопераційний характер. Операційний характер має такі види діяльності:

- виробнича (перетворення ресурсів на новий продукт праці);

- надання послуг (перетворення ресурсів на послугу, роботу);

\footnotetext{
${ }^{1}$ Кудирко, О. М. (2019). Управління товарними операціями підприємств торгівлі. Облік, контроль $і$ аналіз в управлінні підприємнищькою діяльністю: зб. наук. пр. VII Всеукр. наук.-практ. Інтернет-конференція (м.Вінниия 27 берез. 2019 р.), 1, 28-31 <http://www.vtei.com.ua/doc/27_03_19zb1.pdf> (2021, квітень, 10). ${ }^{2}$ Громовик, Б. П. (2014). Методологічні аспекти управління інтегрованими потоковими процесами у фармацевтичній галузі. Фармащевтичний журнал, 3, 3-11.
} 
- продаж виготовленої продукції (товарів, виробів, послуг, робіт) або раніше придбаних ресурсів (торгівля).

Неопераційний характер, також і для підприємств роздрібної торгівлі, має інвестиційна та фінансова діяльність.

Бухгалтерський облік як інформаційна база управління має генерувати релевантну інформацію для прийняття як поточних, так і стратегічних рішень щодо їх оперативності та ефективності. Методологію побудови та організацію бухгалтерського обліку фінансових результатів діяльності підприємств торгівлі фармацевтичними товарами формують, як правило, три принципи: принцип облікового періоду, принцип відповідності та принцип нарахування.

Одиницею бухгалтерського обліку лікарських препаратів та фармацевтичних товарів $є$ їх найменування, або однорідна група. Придбання товарів оформляється договором, який підписується між постачальником та покупцем. Надходження товарів відображається на підставі накладних, товарно-транспортних накладних типової форми. У бухгалтерському обліку ТОВ «ТIIМ» до категорії товарів відносять матеріальні цінності, що придбанні/отриманні та утримуються підприємством 3 метою подальшого продажу.

Як засвідчив аналіз економічної літератури, «процес організації обліку можна поділити на три етапи: первинний, поточний і підсумковий». Тому, на наш погляд, необхідно починати цей процес з раціонально орієнтованого документообігу. У цьому зв'язку у табл. 1 пропонуємо графік документообігу з обліку товарів для підприємств роздрібної торгівлі фармацевтичними товарами. 3 його допомогою здійснюється контроль за торговельним процесом, приймаються оперативні рішення щодо підвищення його ефективності та результативності ${ }^{1}$.

Таблиця 1

Документограма обліку товарів від операційної діяльності для підприємств роздрібної торгівлі фармацевтичними товарами

\begin{tabular}{|c|c|c|c|c|c|c|}
\hline \multirow[t]{2}{*}{ Назва документу } & \multicolumn{6}{|c|}{ Утворювачі та користувачі інформації } \\
\hline & Комірник & $\begin{array}{l}\text { Продавець- } \\
\text { касир }\end{array}$ & $\begin{array}{c}\text { Діюча } \\
\text { комп'ютерна } \\
\text { система }\end{array}$ & Бухгалтер & $\begin{array}{l}\text { Головний } \\
\text { бухгалтер }\end{array}$ & Архів \\
\hline $\begin{array}{l}\text { 1. Накладна на } \\
\text { передачу ліків } \\
\text { в торговий зал }\end{array}$ & ZBR & & & & & \\
\hline $\begin{array}{l}\text { звіт РРО } \\
\text { (реалізація за } \\
\text { готівкові } \\
\text { кошти та їх } \\
\text { еквіваленти) }\end{array}$ & I & I & & & & \\
\hline $\begin{array}{l}\text { 2.Товарний } \\
\text { Звіт }\end{array}$ & & & & & & \\
\hline $\begin{array}{l}\text { 4. Журнали- } \\
\text { ордери 5, 5A, } 6\end{array}$ & & & & & & \\
\hline $\begin{array}{l}\text { 3.Головна } \\
\text { Книга }\end{array}$ & & & & & & \\
\hline
\end{tabular}

Джерело: розроблено авторами

\footnotetext{
${ }^{1}$ Копчикова, I. В. (2019). Фактографічне забезпечення обліку та внутрішнього контролю товарних втрат торговельних мереж. Облік, контроль і аналіз в управлінні підприємницькою діяльністю : зб. наук. пр. VII Всеукр. наук.-практ. Інтернет-конференція (м.Вінниия 27 березня 2019 р.), 1, 18-21. <http://www.vtei.com.ua/doc/27_03_19zb1.pdf> (2021, квітень, 10).
} 
Недоліки в розробці схем руху документів (документообігу) часто є причиною незадовільної організації обліку витрат, доходів в цілому.

При організації поточного обліку товарів під час реалізації та його складових насамперед необхідно звернути увагу на План рахунків та його відповідність потребам внутрішніх користувачів облікової інформації.

Робочий план рахунків ТОВ «ТІІМ» гарантує таку організацію обліку доходів, витрат та фінансових результатів, щоб дані рахунків можна було використовувати як у фінансовому, так і в управлінському обліку. Для цього, на наш погляд, у Робочому плані необхідно чітко розмежувати витрати, доходи та фінансові результати за видами діяльності, що здійснюються в підприємствах торгівлі.

Насамперед необхідно зазначити зміни, які відбудуться в робочому Плані рахунків підприємства в класах доходів та витрат, що стане підгрунтям для підвищення аналітичності інформації, а саме: до рахунку 70 «Дохід від реалізації» доцільно відкрити субрахунки третього порядку:

7021 «Дохід від реалізації фармацевтичних товарів в мережі аптек»;

7022 «Дохід від реалізації фармацевтичних товарів у клініці».

Це дасть змогу в оперативному порядку отримати інформацію про обсяг товарообороту за асортиментними групами.

Доходи, витрати і фінансові результати діяльності підприємства визначаються наростаючим підсумком за звітний період. У формуванні фінансового результату від реалізації товарних операцій бере участь чистий дохід. Аналітичний облік реалізованої продукції має на меті виявити ефективність (рентабельність) реалізації окремих видів або груп продукції (товарів), виконаних робіт і наданих послуг, а також за формами реалізації, регіонами і іншими параметрами.

Аналіз товарних операцій підприємств торгівлі має вагоме значення в системі управління даними ресурсами відповідних підприємств. Аналіз, як функція управління грунтується на даних системи бухгалтерського обліку та зокрема кінцевого елемента функціонування даної системи фінансовій звітності підприємства. Одночасно, аналіз є складовою, в рамках якої формується інформаційне забезпечення системи управління товарними операціями підприємств торгівлі.

В процесі аналізу товарних операцій підприємств торгівлі доцільно виділити мету. Метою аналізу є встановлення ефективності та обгрунтованості системи управління товарними запасами.

Для того, щоб досягти даної мети в процесі аналізу товарних запасів підприємств торгівлі виконується ряд завдань, на реалізацію яких спрямовуються спеціальні методи аналізу. В складі даних завдань доцільно виділити наступні ${ }^{1}$ :

1. Аналіз динаміки товарних запасів підприємства: основного активу, що використовується в рамках товарних операцій підприємств торгівлі.

2. Порівняльний аналіз динаміки товарних запасів із динамікою показників, що характеризують результати торгівельної діяльності та витратну складову, в складі якої товарні запаси на підприємствах торгівлі $\epsilon$ найвагомішим елементом.

3. Аналіз рівномірності нагромадження товарних запасів підприємства, виявлення фактів формування неоптимальних резервів.

4. Визначення планових показників нагромадження товарних запасів підприємства 3 урахуванням різних методів.

5. Проведення вертикального аналізу активів торгівельного підприємства із визначенням частки товарних запасів у їх складі.

6. Визначення показників рентабельності товарних запасів, а також показників рентабельності реалізації підприємством торгівлі його товарних запасів з метою встановлення ефективності товарних операцій, що проводяться підприємством.

7. Проведення факторного аналізу показників рентабельності товарних запасів, а також показників рентабельності реалізації підприємством торгівлі його товарних запасів з метою встановлення чинників, що мають найбільший вплив на зростання показників рентабельності та факторів, що гальмують дане зростання.

Аналіз товарних операцій розпочинається із використання загальних методів аналізу, до яких належить, в першу чергу, аналіз динаміки. Дослідженню з точки зору динаміки підлягає основний об'єкт

\footnotetext{
1 Лобачева, I. Ф., Бондар, Т. Л., Коваленко, В. В.(2019). Діагностика діяльності підприємства. Scientific letters of academic society of Michal Baludansky, 5, 65-67.
} 
товарних операцій - товарні запаси. Основним показником, що розраховується при аналізі динаміки товарних запасів підприємств торгівлі є абсолютне відхилення, яке можна визначати в порівнянні із попереднім роком, або у порівнянні із першим роком досліджуваного проміжку періодів:

Результати аналізу динаміки товарів ТОВ «ТІІМ» узагальнені на рис. 1. Товарні запаси TOB «ТІІМ» найбільшою мірою за весь період, що досліджується, зросли у 2019 р. Їх приріст у абсолютному вимірнику становив 511 тис. грн., а у відносному - 81,34\%. Порівняно із 2015 р. приріст товарних запасів товариства склав 836 тис. грн. у абсолютному вимірнику та 275,73\% у відносному вираженні.

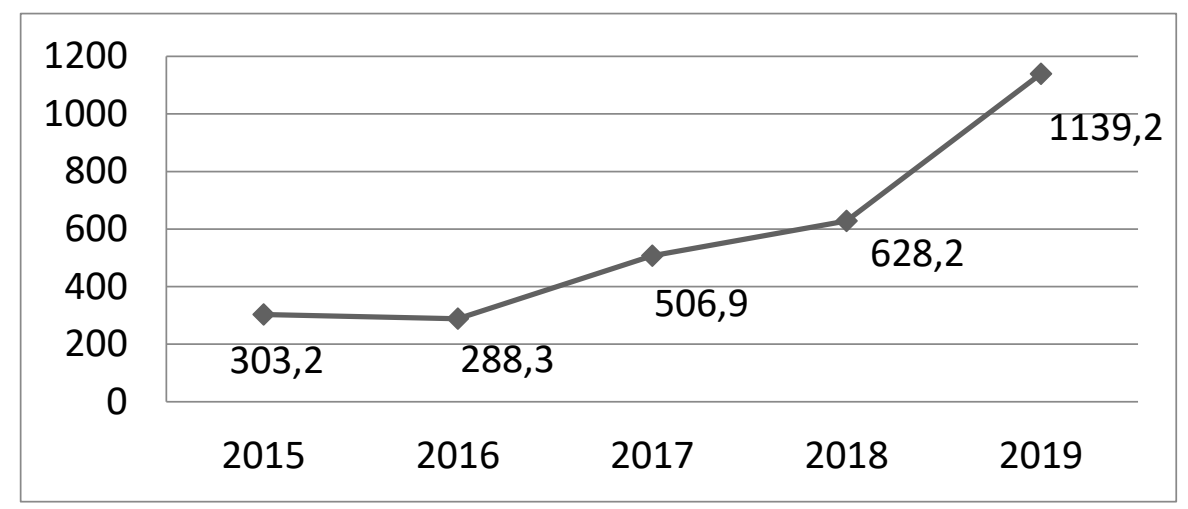

Рис. 1. Аналіз динаміки товарних запасів ТОВ «ТІІМ» за 2015-2019pp.

\section{Джерело: розроблено авторами}

Таким чином, за досліджуваний період відбулося суттєве зростання товарних запасів підприємства, що свідчить про нарощування обсягів діяльності підприємства.

Для підтвердження нарощування обсягів діяльності підприємства та визначення того, на скільки ефективно побудована система управління товарними запасами підприємства доцільно провести порівняльний аналіз темпів зростання товарних запасів, собівартості реалізованих товарів та чистого доходу від реалізації товарів ТОВ «ТІІМ» (Рис. 2).

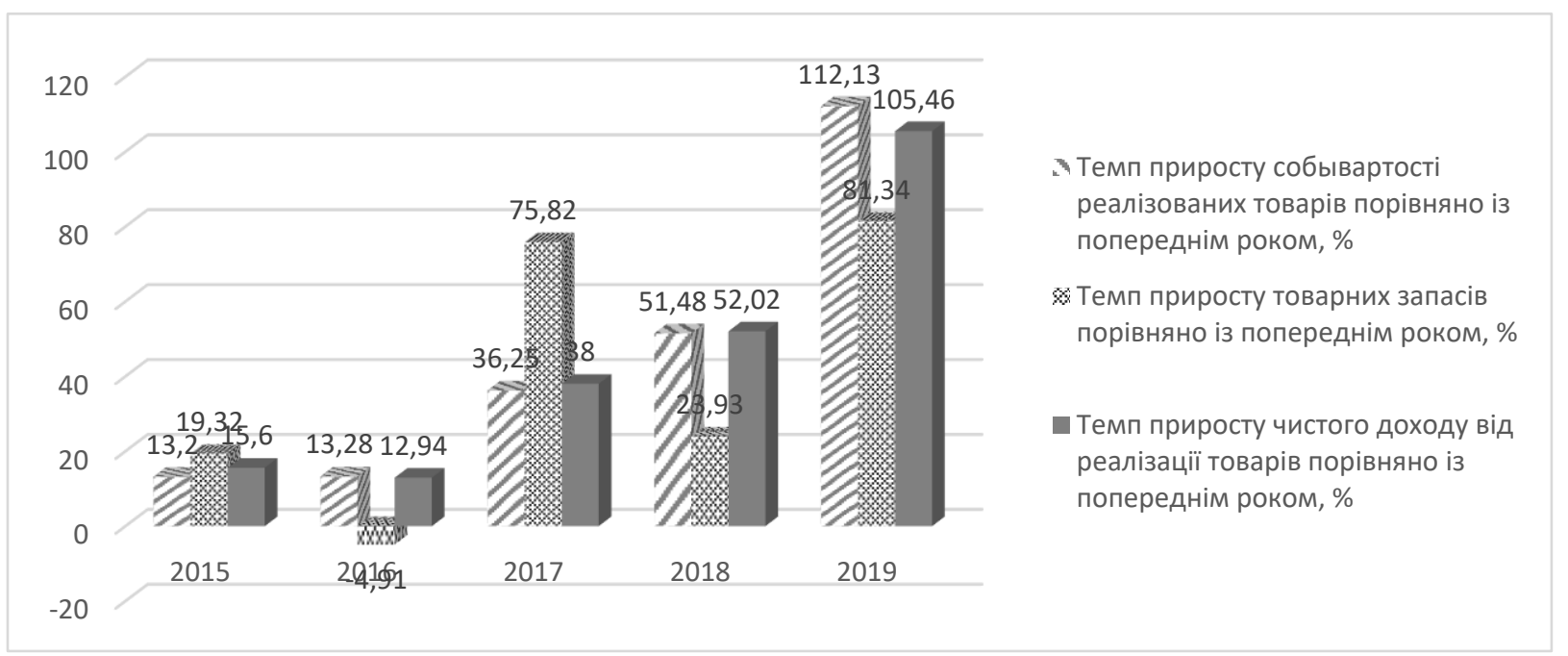

Рис. 2. Аналіз темпів приросту товарних запасів, собівартості реалізації та чистого доходу від реалізації товарів ТОВ «ТІІМ» за 2015-2019 рр.

Джерело: розроблено авторами 
У 2019 р. відбулося суттєве нагромадження товарних запасів на підприємстві. Їх зростання становило 81,34\%, що є досить суттєвим показником та найбільшим за весь аналізований період.

При цьому темп приросту собівартості реалізації товарів суттєво перевищив попередній показник та становив $112,13 \%$. Оскільки рівень залишків товарів на складі не можна вважати досить високим, враховуючи аналізовані показники у 2018 р., то можна висловити думку, що на підприємстві відбулося суттєве нарощування інших витрат, що включаються у собівартість реалізації.

Негативним явищем для 2019 р. було перевищення темпів приросту собівартості реалізованих товарів над темпом приросту чистого доходу від реалізації. Це свідчить про підвищення величини витрат на підприємстві, які, при збереженні сформованої у 2019 р. ситуації в подальші періоди можуть призвести до погіршення ситуації на підприємстві та перевищення витрат над доходами і формування від’ємного фінансового результату на підприємстві.

Аналіз темпів приросту засвідчив нерівномірність постачання товарних запасів на підприємство, що супроводжується ризиком нагромадження резервів, що потребують відповідних потужностей для зберігання.

Для аналізу рівномірності постачання товарних ресурсів використаємо порівняння приросту товарних запасів плановими показниками.

$$
\mathrm{T}_{\mathrm{cr}}=\frac{\mathrm{T}_{\mathrm{n}}-\mathrm{T}_{0-1}}{\mathrm{n}}
$$

Варто відзначити, що на ТОВ «ТІІМ» відсутній план постачання товарних запасів. У зв’язку із цим базою для порівняння має бути середній приріст за досліджуваний період, який становить (1.2):

$$
\mathrm{T}_{\text {сп }}=\frac{1139,2-254,1}{5}=177,02
$$

Таким чином, для досягнення показника, який підприємство мало у 2019 р., виходячи із базового року, що є попереднім для першого року у досліджуваному періоді, тобто 2014 р. середній приріст товарних запасів на підприємстві щороку мав становити 177,02 тис. грн.

При проведенні планування обсягів приросту товарних запасів доцільно враховувати очікуваний приріст доходу підприємства або чистого фінансового результату. Якщо підприємство станом на 2020 р. планує наростити обсяги реалізації на 44\%, то приріст поставок запасів має становити 254,91 тис. грн.

$$
\begin{gathered}
\Delta \mathrm{T}_{\Pi}=\mathrm{T}_{\text {сп }} \times\left(1+\text { ВД}_{\text {вп }}\right) \\
\Delta \mathrm{T}_{\Pi}=177,02 * 1,44=254,91
\end{gathered}
$$

Абсолютний вимірник середньоквадратичного відхилення по приросту товарних запасів становить 310,4 тис. грн.

$$
\delta=\sqrt{\frac{\sum_{i=1}^{n}\left(T_{i}-\bar{T}\right)^{2}}{n}}
$$

Показниками ефективності використання товарних запасів є рівні їх рентабельності. Показники рентабельності товарних запасів ТОВ «ТІІМ» узагальнені в табл. 2 . 
Аналіз рентабельності товарних запасів та їх реалізації ТОВ «ТІІМ» 3a 2015-2019 pp.

\begin{tabular}{|l|c|c|c|c|c|}
\hline \multirow{2}{*}{ Показники } & \multicolumn{5}{|c|}{ Роки } \\
\cline { 2 - 7 } & 2015 & 2016 & 2017 & 2018 & 2019 \\
\hline \multicolumn{5}{|c|}{ Рентабельність товарних запасів, \% } \\
\hline Рентабельність товарних запасів & 36,48 & 28,13 & 33,50 & 39,10 & 60,44 \\
\hline \multicolumn{5}{|c|}{ Рентабельність реалізації товарних запасів, \% } \\
\hline Валова рентабельність реалізації & 15,78 & 15,53 & 16,60 & 16,90 & 14,20 \\
\hline Операційна рентабельність реалізації & 3,85 & 2,14 & 3,28 & 3,18 & 4,05 \\
\hline Чиста рентабельність реалізації & 2,95 & 1,92 & 2,91 & 2,77 & 3,78 \\
\hline
\end{tabular}

Джерело: розроблено авторами

Валова рентабельність реалізації характеризувалася найвищим показником у 2018 p., a операційна рентабельність реалізації була найвищою у 2019 р. Чиста рентабельність реалізації у 2016 р. була найнижчою та становила 1,92\%, а найвищого значення вона досягла у 2019 р. і склала $3,78 \%$.

Таким чином, в цілому товарні запаси та реалізація товарних запасів характеризуються позитивними показниками рентабельності, зростання яких у більшій мірі обумовлено підвищенням прибутку за рахунок націнок, а не скороченням витратної складової.

Висновки. Отже, ефективність функціонування будь-яких підприємств, що займаються торгівлею, значно залежить від правильності здійснення обліку торговельних операцій, а саме товарних запасів та управління ними. Адже від успішності цього процесу залежить рівень ліквідності та конкурентоспроможності підприємства.

Запропоновані основні методи аналізу товарних операцій допоможуть не тільки фармацевтичним, а й усім торговельним підприємствам проаналізувати та врегулювати свою діяльність, підвищити рентабельність та швидкість обертання вкладеного капіталу.

\section{References:}

1. Kudyrko O. M. (2019). Upravlinnia tovarnymy operatsiiamy pidpryiemstv torhivli [Management of commodity operations of trade enterprises]. Oblik, kontrol i analiz v upravlinni pidpryiemnytskoiu diialnistiu [Accounting, control and analysis in business management], I, 28-31. 〈http://www.vtei.com.ua/doc/27_03_19zb1.pdf> [in Ukrainian].

2. Hromovyk, B. P. (2014). Metodolohichni aspekty upravlinnia intehrovanymy potokovymy protsesamy $\mathrm{u}$ farmatsevtychnii haluzi [Methodological aspects of integrated flow management in the pharmaceutical industry]. Farmatsevtychnyi zhurnal [Pharmaceutical Journal], 3, 3-11. [in Ukrainian].

3. Kopchykova, I. V. (2019). Faktohrafichne zabezpechennia obliku ta vnutrishnoho kontroliu tovarnykh vtrat torhovelnykh merezh. [Factual support of accounting and internal control of commodity losses of retail chains]. Oblik, kontrol i analiz v upravlinni pidpryiemnytskoiu diialnistiu [Accounting, control and analysis in business management], I, 18-21. <http://www.vtei.com.ua/doc/27_03_19zb1.pdf> [in Ukrainian].

4. Lobacheva, I. F., Bondar, T. L., Kovalenko, V. V. (2019). Diahnostyka diialnosti pidpryiemstva. [Diagnosis of enterprise activity]. Scientific letters of academic society of Michal Baludansky, 7, 4, 65-67. [in Ukrainian]. 